\title{
DISEMINASI PENGGUNAAN PROBIOTIK PADA BROILER DI KELOMPOK PETERNAK PARAS
}

\author{
Dian Septinova $^{1^{* *}}$, Purnama Edy Sentosa $^{1)}$, Riyanti $^{1)}$, dan Rudy Sutrisna ${ }^{1)}$ \\ ${ }^{1}$ Jurusan Peternakan, Fakultas Pertanian, Universitas Lampung, Bandar Lampung \\ Jl. Prof. Sumantri Brojonegoro No.1 Bandar Lampung 35145 \\ Penulis Korespodensi : dian.septinova@fp.unila.ac.id
}

\begin{abstract}
Abstrak
Kelompok Peternak Paras (Perkampungan Ayam Ras) adalah kelompok peternak yang bergerak di bidang usaha ayam ras khususnya ayam broiler. Kendala yang selama ini dihadapi oleh Kelompok Peternak Paras adalah tingginya biaya ransum dan sapronak, rendahnya produksi, dan kasus penyakit NC, Pullorum, dan CRD. Berdasarkan masalah tersebut, maka solusi yang ditawarkan oleh Tim pengabdian Unila adalah (1) meningkatkan kemampuan anggota kelompok ternak ini mempunyai daya saing yang tinggi, (2) memperbaiki manajemen pemeliharaan yang ada (3) mengenalkan bioteknologi probiotik untuk meningkatkan efisiensi ransum dan produksi broiler, (4) menjelaskan teknik biosekuriti dan vaksinasi yang tepat untuk pencegahan penularan penyakit ke dan dari ayam. Metode kegiatan yang digunakan adalah Participatory Rural Apraisal (PRA), yaitu suatu Metode pendidikan kepada masyarakat melalui penyuluhan, pelatihan, dan demplot. Hasil pengabdian menunjukkan bahwa pengetahuan dan ketrampilan masyarakat mengenai manajemen pemeliharaan broiler dengan pemberian probiotik meningkat, produksi broiler yang diberi probitik pun terbukti lebih baik dibanding kontrol, sehingga peternak di Kelompok Paras pun tertarik untuk mengembangkan broiler probio.
\end{abstract}

Kata kunci : ayam, broiler, probiotik

\section{Pendahuluan}

Hingga saat ini daging ayam broiler masih menjadi primadona untuk konsumsi masyarakat. Kondisi ini menarik minat beberapa masyarakat peternak untuk beternak broiler. Tetapi sangat disayangkan animo peternak terhadap komoditi yang satu ini tidak disertai kestabilan keuntungan yang dapat diraih oleh peternak, sehingga seringkali kita dengar banyak peternak yang gulung tikar.

Kelompok peternak Paras (Perkampungan Ayam Ras) adalah kelompok ternak yang bergerak di bidang usaha ayam ras khusunya broiler. Kelompok peternak ini berlokasi di Desa Margorejo, Kecamatan Jati Agung, Kabupaten Lampung Selatan. Lokasi ini hanya berjarak sekitar $30 \mathrm{~km}$ dari Bandar Lampung yang merupakan tempat pemasaran utama dari produk ayam broiler yang mereka hasilkan.
Kelompok Peternak Paras didirikan pada tahun 2008. Kelompok ternak ini dibentuk karena adanya keinginan untuk berusaha bersama dalam satu tujuan, yaitu peningkatan kesejahteraan. Adanya kelompok ternak ini diharapkan para anggotanya bisa beternak yang lebih baik dari segi manajemen pemeliharaan, penggunaan teknologi, permodalan, dan pemasaran produk ternak yang akan dihasilkan.

Pemilihan Kelompok Peternak Paras sebagai mitra pada kegiatan ini didasarkan pada beberapa pertimbangan, yaitu: (1) ayam broiler mempunyai kontribusi yang sangat penting bagi peningkatan pendapatan dan pemenuhan gizi keluarga, (2) Kelompok Peternak Paras telah berdiri cukup lama yaitu sejak tahun 2008, (3) permintaan masyarakat akan daging broiler sangat tinggi, (4) minat kelompok Paras memajukan usaha ayam broilernya tinggi; (5) lokasi peternakan yang tidak jauh dengan tempat 
SAKAI SAMBAYAN — Jurnal Pengabdian kepada Masyarakat

pemasaran yaitu sekitar $30 \mathrm{~km}$ dari Bandar Lampung.

Berdasarkan fakta yang ada, pemeliharaan ayam yang dilakukan oleh Kelompok Paras mempunyai beberapa kendala. Tingginya biaya ransum, rendahnya produksi, dan penyakit broiler merupakan masalah yang kerap kali dihadapi oleh Kelompok peternak Paras. Oleh sebab itu, perlu ada sentuhan teknologi seperti probiotik yang dapat meningkatkan efisiensi produksi ayam broiler sehingga keuntungan yang diperoleh peternak ini dapat meningkat.

Probiotik merupakan tambahan pakan yang mengandung mikroba hidup yang keberadaanya memperbaiki keseimbangan mikroorganisme dalam saluran pencernaan (Daud dkk., 2007). Probiotik merupakan suplemen yang berisi mikroba hidup dan memberi pengaruh menguntungkan (kesehatan) untuk saluran pencernaan (Brady dkk., 2000). Menurut Soeharsono (1997), secara umum fungsi probiotik meningkatkan pertumbuhan dan meningkatkan kesehatan ternak dengan jalan menekan pertumbuhan mikroorganisme yang tidak diinginkan dan merangsang kerja mikroorganisme non patogen.

Manfaat probiotik bagi ayam broiler diantaranya adalah meningkatkan daya cerna ayam sekaligus menghambat pertumbuhan bakteri patogen dalam saluran pencernaan. Peningkatan daya cerna ayam ini menyebabkan pakan yang terserap dapat lebih sempurna sekaligus saluran pencernaan ayam menjadi lebih sehat. Selain itu, dengan penggunaan probiotik, pakan yang terserap dapat diolah lebih efisien menjadi daging (Jayanata, 2011). Menurut Agustina (2000), penggunaan probiotik dapat menekan jumlah kematian ayam broiler. Berdasarkan penelitian Gunawan dan Sundari (2003), penggunaan probiotik dosis mulai dengan $0,25 \%$ dalam pakan yang diberikan setiap hari dapat meningkatkan pertambahan bobot badan broiler hingga umur 6 minggu. Menurut hasil penelitian Pratiwi (2016), pemberian probiotik $45 \mathrm{~mL} / \mathrm{kg}$ pakan menghasilkan pertumbuhan terbaik dengan rata-rata laju pertumbuhan tertinggi pada minggu ke-3 - 4 sebesar 584,29 \pm 60,51 g/ayam begitu juga dengan produktivitas sebesar 1664,29 \pm 98,802 g/ayam.

Penggunaan probiotik merupakan tindakan yang terbukti dapat meningkatkan produksi broiler sehingga diharapkan dapat meningkatkan pendapatan peternak. Berdasarkan hal itu, maka kegiatan penyuluhan mengenai diseminasi penggunaan probiotik untuk ayam broiler di Kelompok peternak Paras ini dilakukan.

\section{Metode}

Khalayak sasaran kegiatan ini adalah para peternak di Kelompok Peternak Paras, Ibu-ibu rumah tangga, dan masyarakat yang berminat. Dari para peserta ini diharapkan juga mampu menularkan informasi ini kepada peternak yang lain atau masyarakat lain yang berminat beternak

Metode kegiatan yang digunakan adalah Participatory Rural Apraisal (PRA), yaitu suatu metode pendidikan kepada masyarakat melalui penyuluhan, pelatihan, dan demplot. Materi penyuluhan yang disampaikan adalah mengenai (1) produksi daging ayam broiler yang sehat, (2) manajemen kesehatan broiler: manajemen kesehatan usus, (3) Penggunaan probiotik bagi broiler, dan 4) Diagnosa dan pencegahan penyakit broiler. Pelatihan dan demplot yang dilakukan adalah manajemen pemeliharaan broiler mulai dari DOC sampai panen (25 hari) dengan pemberian probiotik dan program vaksinasi.

Evaluasi kegiatan pengabdian kepada masyarakat ini dibagi menjadi tiga tahap, yaitu:

(1) Evaluasi awal (pre-test), dengan memberikan test yang berupa daftar pertanyaan (kuisioner), dilakukan sebelum kegiatan penyampaian materi; (2) Evaluasi proses, dilakukan untuk menilai keadaan selama kegiatan pelatihan berlangsung. Evaluasi ini dilakukan untuk setiap komponen yang berhubungan langsung dengan kegiatan dalam program pelatihan. Sebagai indikator utama dalam kegiatan evaluasi proses meliputi kehadiran dan 
SAKAI SAMBAYAN — Jurnal Pengabdian kepada Masyarakat

perhatian, serta aktivitas dan tanggapan peserta selama kegiatan berlangsung.

(3) Evaluasi akhir (post-test), dengan memberikan test yang berupa daftar pertanyaan (kuisioner), dilakukan setelah kegiatan penyampaian materi, diskusi, dan demonstrasi model.

\section{Hasil dan Pembahasan}

\section{A. Peserta}

Peserta kegiatan penyuluhan ini diikuti oleh 34 orang peserta yang merupakan anggota kelompok Paras dan juga warga sekitar yang tertarik untuk ikut beternak broiler. Jumlah peserta penyuluhan yang ditargetkan adalah 20 orang, jadi target tersebut tercapai lebih dari $100 \%$. Semua peserta mengikuti kegiatan dari awal hingga selesai.

\section{B. Analisis Evaluasi}

Pelaksanaan pengabdian ini menggunakan metode ceramah, diskusi, dan demplot. Selain itu peserta juga diajak untuk menyaksikan vidio mengenai pemeliharaan ayam dengan probiotik.

Setelah kegiatan penyampaian materi dan pemutaran vidio, dilakukan kegiatan diskusi. Kegiatan diskusi yang dilakukan berlangsung menarik. Peserta penyuluhan tertarik untuk mengetahui lebih lanjut tentang penggunaan probiotik dan prospek beternak ayam probio. Selain pertanyaan seputar probiotik, peternak juga banyak mengajukan pertanyaan tentang penyakit dan obat-obatan untuk broiler. Peternak juga berbagi cerita tentang praktik pemeliharaan broiler yang selama ini mereka lakukan. Berdasarkan cerita dari beberapa peternak, ternyata selama ini sudah ada peserta yang memberikan perlakuan jamu-jamuan dan EM4 pada broilernya hanya saja mereka tidak paham kalau yang mereka berikan itu disebut probiotik.

\section{Evaluasi awal}

Kegiatan evaluasi awal dilakukan sebelum kegiatan penyuluhan dilakukan, yaitu dengan kunjungan ke ketua kelompok peternak untuk menanyakan masalah seputar broiler yang selama ini menjadi kendala mereka di dalam beternak. Selanjutnya melakukan koordinasi dengan ketua kelompok Paras yang juga Kepada Desa Wawasan sebagai persiapan untuk melakukan kegiatan penyuluhan terkait dengan ayam broiler probiotik. Setelah itu dilakukan kegiatan penyuluhan kepada anggota kelompok PARAS dan beberapa warga Desa Wawasan yang bertempat di Balai Desa Wawasan.

Selain evaluasi awal kepada ketua kelompok tentang permasalahan ayam broiler, evaluasi awal juga dilakukan kepada peserta penyuluhan yang hadir. Kegiatan evaluasi awal dilaksanakan sekitar 15 menit sebelum kegiatan ceramah dan diskusi dilaksanakan. Hasil evaluasi menunjukkan bahwa walaupun peternak kelompok Paras sudah lama memeliharan broiler, namun rataan tingkat pemahaman mereka tentang produk broiler sehat, manajemen kesehatan, probiotik, dan manajeman pencegahan dan pengobatan penyakit untuk broiler masih tergolong rendah $(45,60)$.

\section{Evaluasi proses}

Kegiatan penyuluhan dilakukan dalam bentuk ceramah, diskusi, dan demplot pemeliharaan ayam broiler dengan menggunakan probiotik. Pada materi produksi daging broiler yang sehat dan efisien dijelaskan tentang bahaya pemakaian antibiotik bagi konsumen daging broiler dan bahan-bahan alami seperti probiotik, prebiotik, asam organik, enzim, dan fitobiotik yang dapat dijadikan alternatif penggunaan antibiotik. Tahapan-tahapan yang harus dilakukan untuk produksi broiler yang efisien yaitu (1) perbaikan ransum, (2) perbaikan manajemen, (3) perbaikan pada sistem penyembelihan. Ransum broiler pada minggu pertama harus mendapat perhatian karena akan sangat menentukan capaian bobot badan akhir saat panen. Pemberian ransum dengan komposisi yang komplit dan berimbang penting untuk mengatasi stress panas pada ayam. 


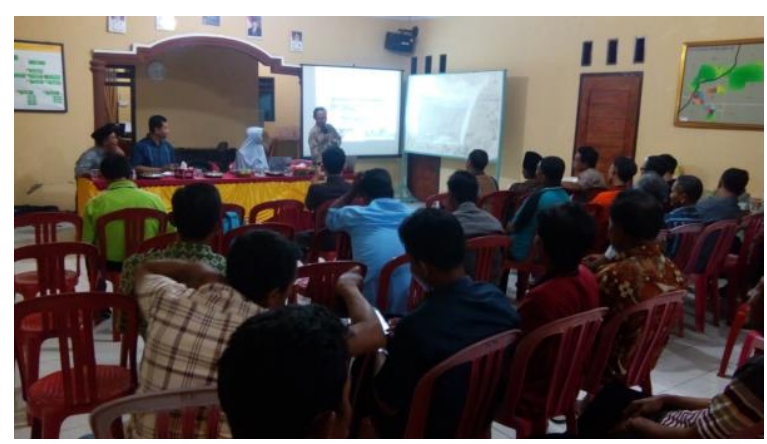

Gambar 1. Penyampaian materi penyuluhan pada peserta

Pada materi ke dua tentang manajemen kesehatan dijelaskan dampak kesehatan system pencernanaan bagi produksi unggas, manjemen pemeliharaan yang harus dilakukan untuk menjamin kesehatan system pencernaann.

Pada materi ketiga tentang pemanfaatan probiotik pada broiler dijelaskan tentang apa itu probiotik, manfaat probiotik bagi broiler, pembuatan probiotik, dan juga minuman fitobiotik atau yang dikenal peternak sebagai jamu-jamuan. Pada kesempatan ini juga dijelaskan tentang probiotik yang ada di pasaran dan cara mudah pembuatan dan pemakaian probiotik.

Pada materi yang ke empat tentang strategi pencegahan penyakit pada broiler dijelaskan tentang cara pencegahan penyakit dengan biosekurity, vaksinasi, dan biosekuriti. Pada kesempatan tersebut juga dijelaskan tentang penyakit-penyakit infeksius yang menyerang ayam broiler dan penanganannya.

Kegiatan ceramah ini mendapat respon yang cukup baik dari peserta. Hal ini dapat dilihat dari jumlah peserta yang hadir melebihi jumlah yang ditargetkan. Jumlah peserta yang ditargetkan adalah 20 orang, ternyata peserta yang hadir berjumlah 34 orang.

Kegiatan ceramah dilanjutkan dengan sesi tanya jawab. Sesi ini mendapat perhatian yang bagus dari peserta. Hal ini terlihat dari dari banyaknya pertanyan yang disampaikan seputar produksi ayam broiler probiotik

Selain ceramah, kegiatan penyuluhan juga dilakukan dalam bentuk demplot pemeliharaan ayam broiler dengan pemberian probiotik.
Demplot pemeliharaan diukan di peternakan broiler milik ketua Kelompok Paras yaitu Bapak Budiyono.

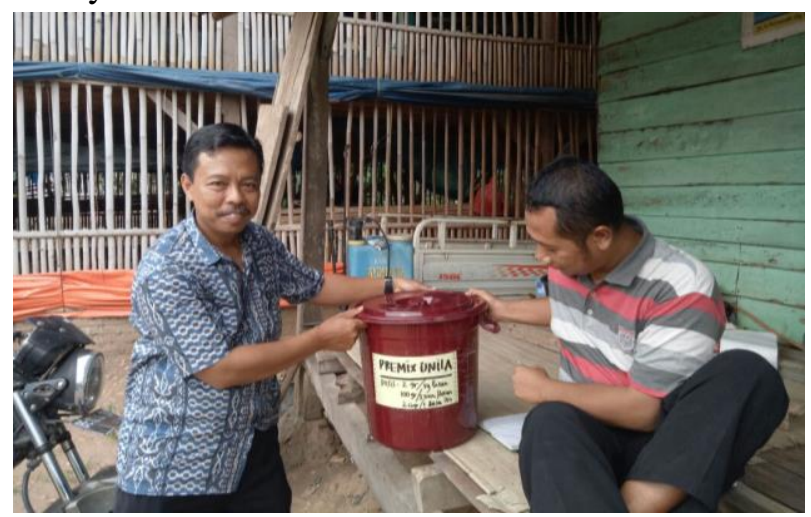

Gambar 2. Penyerahan probiotik siap pakai ke peternak

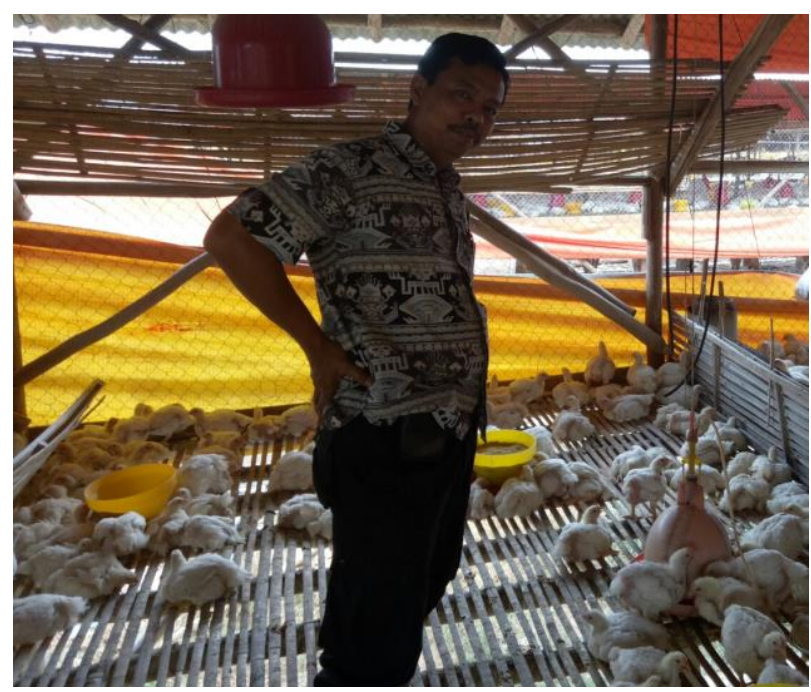

Gambar 3. Peninjauan ke kandang peternak lokasi demplot

\section{Evaluasi akhir}

Kegiatan evaluasi akhir dilaksanakan setelah kegiatan ceramah dan diskusi. Kegiatan ini bertujuan untuk mengetahui tingkat kemajuan pemahaman yang dicapai oleh sasaran. Evaluasi akhir dilaksanakan dengan memberikan daftar pertanyaan yang sama pada waktu evaluasi awal. Hasil evaluasi akhir peserta memperlihat bahwa pengetahuan peserta mengenai materi yang disampaikan sangat meningkat. Tingkat pemahaman peserta yang semula masuk dalam kategori rendah $(45,60)$ meningkat menjadi tinggi (100). Pengetahuan yang sudah diterima peserta ini selanjutnya diharapkan dapat diterapkan pada 
SAKAI SAMBAYAN — Jurnal Pengabdian kepada Masyarakat

pemeliharaan ayam broiler sehingga produksi ayam broiler broilernya menjadi lebih baik. Kegitan penyuluhan ini merupakan kegiatan pengenalan, ke depannya diharapkan ada peserta yang tergerak untuk berusaha di bidang usaha broiler probio.

Pada kegiatan demplot, hasil yang didapat oleh peserta adalah bimbingan teknis tentang penggunaan probiotik, biosekuriti, vaksinasi, deteksi dan pengobatan penyakit broiler. Selama ini peternak memelihara broiler hanya berdasarkan pengalaman dan prosedur kerja yang diberikan oleh peruhaaan (inti). Seringkali peternak tidak paham tentang adanya penyakit dan cara penanganannya yang tepat untuk ayam broiler sehingga merugikan peternak. Peternak juga diajarkan cara pengobatan penyakit pada ayam broiler dengan obat-obatan alami dan juga obat-obatan yang harganya murah namun terbukti ampuh untuk mengobati penyakit broiler, sehingga pengeluaran untuk obat-obatan dapat dikurangi.

Berdasarkan hasil demplot, performans ayam broiler yang diberi probiotik herbal secara keseluruhan lebih baik daripada ayam broiler yang tidak diberi probiotik herbal (kontrol). Indeks Data performan ayam broiler yang diberi probiotik herbal dapat dilihat pada Tabel 3.

Tabel 3. Performans ayam broiler dengan pemberian probiotik-herbal

\begin{tabular}{|l|r|r|}
\hline \multirow{2}{*}{ Uraian } & \multicolumn{2}{|c|}{ Ayan broiler } \\
\cline { 2 - 3 } & Kontrol & \multicolumn{1}{|c|}{$\begin{array}{c}\text { Probiotik } \\
\text { herbal }\end{array}$} \\
\hline Jumlah awal (ekor) & 110 & 110 \\
Jumlah akhir (ekor) & 110 & 110 \\
Mortalitas (\%) & 0 & 0 \\
Rataan bobot badan & & \\
(g/ekor) & 189,92 & 191,27 \\
Minggu ke-1 & 495,67 & 502,00 \\
Minggu ke-2 & 895,67 & 913,33 \\
Minggu ke-3 & 1084,64 & 1047,82 \\
Hari ke-25 & & \\
Feed Intake & & \\
(g/ekor/minggu) & 49,61 & 44,68 \\
Minggu ke-2 & 93,25 & 90,13 \\
Minggu ke-3 & 104,79 & 97,09 \\
Hari ke-25 & & \\
FCR & 1,14 & 1,04 \\
$\quad$ Minggu ke-2 & & \\
\hline
\end{tabular}

\begin{tabular}{|l|r|r|}
\hline \multicolumn{1}{|c|}{ Minggu ke-3 } & 1,42 & 1,30 \\
$\quad$ Hari ke-25 & 1,47 & 1,29 \\
Total Pakan hari 8-25 & & \\
(kg) & 144,58 & 135,84 \\
Indeks Produksi & 253,72 & 311,60 \\
\hline
\end{tabular}

\section{Kesimpulan}

Kesimpulan yang bisa diambil dari kegiatan pengabdian masyarakat adalah: (1) kegiatan ini berhasil meningkatkan pengetahuan dan keterampilan peserta tentang produksi ayam broiler sehat, manajemen pemeliharaan dan kesehatan broiler, probiotik dan penggunaan probitik bagi peningkatan produksi ayam broiler dari 45,50 menjadi 100, (2) Pemakaian probitik terbukti mampu meningkatkan performan ayam broiler.

\section{Ucapan Terima Kasih}

Penulis mengucapkan terimakasih kepada LPPM Universitas Lampung yang telah mendanai kegiatan pengabdian masyarakat ini melalui Hibah DIPA BLU pengabdian Dosen senior 2017. Penulis juga mengucapkan terimakasih kepada Kepada Desa Wawasan dan kelompok Paras sebagai mitra atas kerjasamanya.

\section{Daftar Pustaka}

Agustina, L., S. Purwanti dan D. Zainuddin. 2000. Penggunaan probiotik (Lactobacillus sp.) sebagai imbunahan pakan broiler. Seminar nasional Teknologi Peternakan dan Veteriner: $552-555$.

Brady, L.J., D.D Gallaher and F.F Busta. 2000. The role of probiotic cultures in the prevention of colon cancer. J. Nutr. 130: $4105-4145$.

Daud, M., W.G. Piliangdan I.P., dan Kompiang. 2007. Persentase dan kualitas ayam pedaging yang diberi probiotik dan prebiotik dalam Ransum. JITV 12 (3): $167-174$.

Gunawan dan Sunandari. 2003. Pengaruh penggunaan probiotik dalam ransum terhadap produktivitas ayam.

http://peternakan.litbang.go.id/fullteks/wartazo al33-2pdf. 
SAKAI SAMBAYAN — Jurnal Pengabdian kepada Masyarakat

Jayanata, C.E., dan H. Bagus. 2011. 28 Hari Panen Ayam Broiler. PT. Agromedia. Jakarta.

Pratiwi, W. 2016. Pemberian Probiotik Cair dengan Interval Pemberian Satu Kali Seminggu pada Pakan terhadap Pertumbuhan dan Produktivitas
Ayam Ras pedaging (Gallus Domesticus). Skripsi. Departemen Biologi. Fakultas Sains dan Tekonologi. Universitas Surabaya.

Soeharsono. 1997. Probiotik alternatif pengganti antibiotik. Buletin PPSKI $9: 10$ 